\title{
O DESENVOLVIMENTO RELIGIOSO: ANÁLISE DE DEPOIMENTOS
}

\author{
RELIGIOUS DEVELOPMENT: \\ PERSONAL REPORTS ANALYSIS
}

Mauro Martins AMATUZZI ${ }^{1}$

\begin{abstract}
RESUMO
São descritas nove etapas hipotéticas do desenvolvimento religioso, de acordo com um artigo anteriormente publicado nesta revista. À luz desta construção teórica alguns depoimentos pessoais de histórias religiosas são qualitativamente analisados. Principais conclusões: 1) o modelo das 9 etapas permitiu uma compreensão aprofundada dos depoimentos; 2) existe uma íntima relação entre o aspecto religioso e o psicológico do desenvolvimento humano-pessoal; 3) o grau de desenvolvimento religioso não depende tanto da religião declarada, mas sim, mais C/o tipo de relação com o objeto religioso; 4) a etapa em que se encontra a pessoa nem sempre coincide com o que seria de se esperar para a sua idade, e isso pode estar relacionado com outros aspectos do desenvolvimento religioso.
\end{abstract}

Palavras-chave: desenvolvimento psicológico, religiosidade, religião, desenvolvimento religioso.

\begin{abstract}
Nine hypothetical stages for religious development are described, according to a preceding article printed in this journal. Under the light of this theoretical construction some personal reports of religious history are qualitatively analysed. Main conclusions are: 1) the nine stages model of the religious development allows a deep understanding of the personal reports; 2) there is a close relationship between the religious and the psychological side of the personal development; 3) the religious development degree depends more on the character of the relationship with the religious object than on the professed religion; 4) the stage of
\end{abstract}

(1) PUC.Campinas, maior de 2000. Tel:289-2635. E-mail: amatuzm2@ cosmo.com.br. 
religious development of a person does not always depend on what it would be expected for his or her age, and it could be related with other aspects of the psychological development in general.

Key-words: psychological development, religion, religiousness, religious development.

Este artigo dá continuidade a um anterior que teve como título "O desenvolvimento religioso: uma hipótese psicológica" (Amatuzzi, 2000). Tratamos ali de montar uma hipótese geral do desenvolvimento religioso do ponto de vista psicológico, baseando-nos em outros estudos acerca do desenvolvimento humano, principalmente os de Piaget, Jung, Maslow, Kohlberg, Erickson, Fowler, e Oser \& Gmünder, os quais foram relatados na medida em que tiveram influência na construção de nosso modelo (Piaget, 1967; Jung, 1979; Maslow, s/d; Camino, 1998; Erickson, 1998; Fowler, 1992; Oser \& Reich, 1996). Contudo, também, devemos dizer que a construção da hipótese teve como referência nossa experiência em trabalhos com grupos de reflexão sobre o desenvolvimento pessoal (Amatuzzi, 1988; e Amatuzzi, Echeverria, Brisola, \& Giovelli, 1996). Nove etapas do desenvolvimento religioso foram descritas, desde a primeira infância até a velhice. Cada etapa gira em torno de uma das experiências básicas de que se constitui o viver humano, e descreve o desenvolvimento em seu aspecto de contato com o objeto religioso.

Religião está sendo entendida aqui como relação pessoal com as coisas a que se referem os significados últimos da vida. Por isso também usamos o termo quase-religião: para indicar aquela relação quando os significados últimos não são concebidos como tendo uma referência ao divino ou absolutamente transcendente. Vivência religiosa está sendo entendida como tudo aquilo que a pessoa pode contar sobre sua história pessoal no campo religioso ou no campo das indagações pelo sentido último.
Experiência religiosa se refere a algum acontecimento decisivo e marcante no campo da tomada de posição face a um sentido último.

Poderíamos resumir agora a descrição das nove etapas de nossa hipótese geral. Para maiores detalhes o leitor deverá reportar-se ao artigo anteriormente mencionado.

1a etapa: o bebê ( 0 a 1,5 anos)

$O$ desafio central a ser enfrentado no processo deformação de um eu consciente no primeiro ano de vida, apresenta-se como um passar do sonho à realidade) e descobrir um mundo independente do eu. A experiência básica que está intimamente ligada à superação deste desafio, éo de uma confiança fundamental, tecida no aconchego da relação com os pais, e capaz de tirar a pessoa de dentro de si mesma e fazê-la viver neste mundo.

Essa confiança básica é o fundamento de todas as formas posteriores de fé ou religião. Falhas aqui (a recusa, a hesitação, ou a negociação da confiança) terão conseqüências sobre a experiência religiosa posterior. Para o bebê, contudo, não há muito sentido falar-se em religião, a não ser como religião da família.

\section{2ªpa: a criança (2 a 6 anos)}

O desafio central é, agora, o de superar um relacionamento possessivo, marcado pelo ciúme, e abrir-se a uma relação onde o outro é aceito em sua separação e autonomia. $A$ experiência que está intimamente ligada com esse tipo de descoberta, é a experiência da linguagem, enquanto reconstrução simbólica 
interior do mundo. Isso acontecendo, a criança se abrirá para a cooperação e o diálogo, e o eu se aceitará como não único.

A religião estará encontrando suas primeiras expressões simbólicas concretas, a partir do que vai sendo recebido. Mais tarde, se houver uma experiência religiosa específica, a pessoa virá a reconhecer nos "símbolos de sua fé" as formas essenciais de expressão de seu vivido. A ocorrência limitada da experiência da linguagem (por exemplo, o predomínio de uma linguagem convencionale não expressiva), impedirá ou dificultará a existência de uma religião refletida, e a pessoa se manterá numa perspectiva imediatista. - Na criança, embora os símbolos sintéticos religiosos ou referentes aos significados últimos já possam ir fazendo algum sentido, as coisas significadas por eles são provavelmente vivenciadas ainda como externas, e carregadas de poder sobre ela.

\section{3a etapa: o menino/a (dos 7 aos 12 anos)}

O desafio central é passar da inabilidade e passividade para a competência e iniciativa, descobrir-se ativo e capaz, ousar fazer. Se esse desafio for superado de forma satisfatória, desenvolve-se a segurança interior e a auto-estima.

A religião (ou quase religião) começa a se expressar agora através de histórias que condensam seu sentido. Falhas na experiência da iniciativa e da ousadia, dificultam o acesso ao sentido das histórias e uma posterior identificação do adulto através da inserção em uma tradição. Nessa idade, embora já possa ir havendo uma apropriação do sentido das narrativas que expressam o sentido último, esse significado se refere ainda, provavelmente, a realidades externas. Contudo a relação com essas realidades já não é de mera passividade: existe a possibilidade de uma influência por parte do sujeito (no caso explicitamente religioso, através de preces, ritos, obediência a preceitos, etc.).
4룰 etapa: o adolescente (dos 13 aos $18 / 20$ anos)

Agora a confiança básica levará o adolescente ao desafio de passar de uma vivência de indefinição, para a de uma definição a partirde si, descobrindo uma verdade pessoal mais profunda. A experiência que se relaciona com isso é a da escolha pessoal.

Nesta época, a religião ou qualquer ideologia referente ao sentido das coisas, como parte da identidade recebida, tende a ser questionada. Deficiências na experiência de escolha bloqueiam esse questionamento $e$ a possível reconstrução posterior de formas mais pessoais dessa atitude básica. Poderá haver um abandono (provisório ou definitivo)da prática religiosa ou quase-religiosa dos pais, justamente porque é dos pais. É possível também que a religião e a vida pessoal do sujeito sejam concebidas ou experienciadas ambas como reais mas separadas ou independentes. A pessoa vai assumindo mais suas escolhas pessoais, e o "mundo religioso" é externo a isso, pertence a outra esfera. Mas também pode acontecer que uma experiência religiosa específica aproxime essas duas esferas.

5ª etapa: o jovem adulto/a (dos $18 / 20$ aos 30 aproximadamente)

O desafio central (se os anteriores foram satisfatoriamente superados) será o de abrir-se para uma relação mais pessoal $e$ profunda, associada à experiência de intimidade. Essa relação não se limita a pessoas; estende-se ao mundo, aos acontecimentos, e descobre algo como uma essência concreta das coisas.

Não é mais possível sustentar uma postura religiosa diante da vida sem que ela seja baseada em uma experiência pessoal, mais crítica e refletida. Posições anteriores já não resistem às exigências do jovem adulto. Uma carência de intimidade (ou relação mais profundamente vivenciada e refletida) aqui, 
afetaria todo o resto do desenvolvimento, inclusive o religioso no sentido amplo. Não havendo experiência pessoal do significado o sujeito poderá ficar apenas com posições pessoais mais ou menos convencionais diante da vida. Por isso mesmo os conceitos religiosos (ou quase-religiosos), quando agora mediados por experiência e reflexão, tendem a aproximar religião e vida. Começa a haver uma integração que, se o desenvolvimento estiver sendo satisfatório, estará sendo trabalhada durante toda a vida adulta.

6a etapa: o adulto (dos 30 aos $35 / 40$ mais ou menos)

Há uma continuação da etapa anterior, consolidando-a na fecundidade: a produção de frutos. O desafio central agora é gerar e cuidar, vivenciando esse novo lado de si próprio que se expande no fruto produzido. $O$ não cumprimento desta tarefa de desenvolvimento tende a produzir o adulto estéril, sem uma participação criativa no meio. Isso se reflete no âmbito do religioso ou das posições em relação aos significados últimos.

A vivência de relação com as realidades a que se referem os significados últimos, se for autêntica, tende a se expandir no meio, criativamente, o que leva a um sentimento de integração maior. Essa vivência poderá fazer a pessoa se sentir instrumento de um desígnio maior, e assim também perceber os outros ou os acontecimentos, numa forma diferente de relação com eles.

$7^{\mathrm{a}}$ etapa: 0 adulto maduro (dos $35 / 40$ aos 60 aproximadamente)

O desafio central na transformação do eu é superar as rotinas e os padrões assumidos e encontrar um sentido mais pessoal para a vida, relativizando as normas e os papéis sociais. As reviravoltas na vida da pessoa nessa época, são sentidas como libertação.
Esse novo apelo pode levara uma religião (ou quase-religião) mais pessoal, superando seus aspectos rígidos e estereotipados, mas também pode levar a um abandono da posição até então vivida (caso não haja um apoio conceitual ou experiencial para essas transformações). Com essa Transformação um passo a mais estará sendo dado na direção da integração entre religião (relação com as realidades últimas) e vida.

8 ${ }^{\text {a }}$ etapa: o adulto mais velho (dos 60 aos 80 mais ou menos)

No processo do eu a pessoa é chamada a aprofundar a libertação a partir de todos os apegos. A confiança básica a leva a descobrir a vida simplesmente, para além dos apoios externos, e daí a sabedoria, para além da ciência.

O sistema de orientação, religioso ou não, se relativiza enquanto sistema. $O$ conceito é, cada vez mais, vivido apenas como instrumento da experiência. Há uma premência maior na busca de um realmente último, na linha da necessidade de transcendência (talvez provocada pela desproporção entre as aspirações cada vez mais espiritualizadas e as perdas). A necessidade de sentido tende a se tornar explicitamente religiosa (embora os conceitos possam não acompanhar). Se a vivência religiosa explícita não recuou para formas rígidas, ela será agora expressão de uma relação experimentada na humildade diante do mistério. Caso isso não ocorra é provável que a pessoa viva em revolta ou amargura. Na melhor das hipóteses a integração entre religião e vida tende a ser tal que esses dois âmbitos da experiência caminham para se fundir. Viver simplesmente (sem nenhum outro apoio, utilidade ou finalidade) é a forma de estar ligado ou religado (ou a forma de religião).

\section{9a etapa: proximidade da morte (...)}

Nesta situação a pessoa vivencia momentos muito especiais em termos de 
desenvolvimento religioso ou humano pessoal. O desafio é, na verdade, passar da vida individual para algo radicalmente diferente, $e$ entregar-se em paz. Caso ocorra isso haverá uma progressiva transcendência do eu empírico com a aceitação da auto-dissolução, e uma abertura para o totalmente outro. A entrega absoluta se constitue no supremo ato religioso (ou implicitamente religioso quando a referência ao transcendente não é conceituada). A revolta, ou a tentativa de segurar-se, podem tornar os últimos tempos de vida ou o ato de morrer extremamente tormentosos. Mas também é possível que a eminência da passagem reconstrua totalmente, na aceitação, as respostas aos desafios da vida. Religião e vida humana não mais se distinguem experiencialmente (embora possam haver conceitos que não atendam à totalidade desta experiência).

Uma vez formulada essa hipótese de conjunto, o objetivo foi entrarmos em contato com histórias religiosas pessoais para verificar se esse quadro referencial poderia ser útil numa compreensão profunda dessas histórias e da natureza do desenvolvimento religioso.

\section{COMO FORAM COLHIDOS OS DEPOIMENTOS}

Houve sempre a preocupação de se colher a história religiosa da pessoa de forma não diretiva, e, tanto quanto possível, aprofundada. Não houve, no entanto, uma fórmula padronizada. Isso foi baseado na suposição de que o importante era se chegar ao vivido, nem que para isso fosse preciso ir além das declarações convencionais. Tal procedimento combina bem com o estilo qualitativo e fenomenológico da pesquisa.

Algumas pessoas foram entrevistadas individualmente, outras em grupo. Mas sempre havia um momento de elaboração pessoal, seja por escrito individualmente, seja oralmente, num diálogo gravado do entrevistador com uma só pessoa, portanto, também individualmente.

De modo geral e sempre que possível buscamos partir de um primeiro depoimento mais externo, para depois, em outro momento, solicitarmos a experiência mais subjetiva, e finalmente, num terceiro momento, fazermos algumas perguntas mais específicas. Isso foi resumido numa espécie de roteiro-instrução, não rígido, como segue.

\section{9 etapa:}

Estamos realizando uma pesquisa em Psicologia sobre como se desenvolvem as tomadas de posição da pessoa no campo religioso. Você gostaria de colaborar conosco fornecendo suas experiências a respeito? Conte-nos sua história religiosa: se sua família tem alguma religião, e como foram se desenvolvendo as suas posições pessoais no campo religioso.

\section{$2^{\text {a }}$ etapa:}

Vamos ler sua história depois de escrita. Será que poderíamos, se for o caso, entrar em contato novamente com você para mais informações sobre algum ponto que não tenhamos entendido bem? Ou para aprofundar um pouco mais algum ponto?

Você poderia comentar mais detalhadamente algumas das frases de seu depoimento, descrevendo como você vivenciou pessoalmente essas experiências, falando-nos de seus sentimentos e pensamentos subjetivos?

\section{3 etapa:}

Para finalizarvocê poderia nos responder a estas 3 perguntas mais específicas?

1) Houve momentos em sua vida em que você sentiu de forma intensa uma outra dimensão da realidade, talvez 
mais profunda, talvez misteriosa e diferente, ou sentiu que existia um sentido maior para todas as coisas, ou sentiu uma presença o que poderia ser chamado de Deus ou algo assim? Pode nos descrever como foram esses momentos ?

2)Houve momentos em que você sentiu de forma intensa que uma outra dimensão da realidade, um sentido maior, ou Deus, ou algo do gênero, seria uma ilusão, um engano, ou algo totalmente incerto? Poderia nos descrever como foram esses momentos?

3) Se você costuma se colocar diante dessa outra dimensão de realidade, dessa presença de Deus ou algo assim, numa atitude de oração ou meditação, poderia nos descrever detalhada mente como você faz isso, ou como se dá isso?

Depois de colher o depoimento procuramos, sempre que possível, solicitar uma autorização expressa para uso desse depoimento em pesquisa, pedindo à pessoa que assinasse um documento neste sentido.

Os depoimentos foram depois transcritos, utilizando-se nomes fictícios para pessoas e lugares, e disponibilizados para a pesquisa.

Os entrevistadores foram o próprio autor deste estudo e alguns auxiliares de pesquisa que se propuseram espontaneamente a colher depoimentos, tendo já, no entanto, passado pela vivência de fornecer o seu próprio, e de refletir sobre as condições de não diretividade na condução da entrevista.

Quando as entrevistas eram em grupo, o procedimento, em geral, seguiu os seguintes passos:

1)Após o convite para a participação se fazia uma reunião, onde cada um contava sua história religiosa sem que nada fosse escrito ou gravado. Havia apenas comentários compreensivos ou empáticos com a finalidade de deixar a pessoa, e o grupo, à vontade, e incentivar algum aprofundamento experiencial.

2)Em casa, e individualmente, cada um escreveu seu depoimento.

3)Numa outra reunião esses depoimentos foram lidos e comentados empaticamente. Também, se fosse o caso, solicitavam-se informações mais detalhadas e pessoais a partir dos pontos de densidade experiencial implícita.

4)Novamente essas complementações eram escritas individualmente, em casa.

5) Finalmente havia uma outra reunião para leitura, eventuais novos comentários, e para resposta oral às 3 perguntas específicas.

6) A resposta escrita às 3 perguntas específicas (juntamente com os outros depoimentos) eram encaminhadas ao pesquisador.

$\mathrm{Na}$ apresentação dos depoimentos há uma pequena nota introdutória para cada um, explicando como essas orientações ocorreram naquele caso particular.

\section{AS PESSOAS QUE FORNECERAM DEPOIMENTOS}

A idéia inicial era entrevistarmos pessoas mais velhas,.com mais experiência de vida, ou com mais histórias para contar. Depois estenderíamos a coleta a outras idades e condições de vida. Até o presente momento foram colhidos 22 depoimentos, 9 de homens e 13 de mulheres. A pessoa mais jovem tinha 21 anos, e a mais velha 81 . Entre essas idades houve pelo menos uma pessoa para cada grupo de 10 anos, sendo que os grupos 
maiores foram: de 20 a 30 anos, com 6 pessoas, e de 40 a 50 anos, com 9 pessoas.

Por coincidência todas as pessoas entrevistadas eram nascidas em famílias, ao menos, parcialmente de tradição católica, mesmo que atualmente já não se considerassem adeptos desta religião. Isso, evidentemente, limita o alcance dos resultados. O título deste estudo, até o presente momento, poderia ser: "o desenvolvimento religioso de pessoas de origem católica".

Dos 22 depoimentos foram escolhidos 8 mais ilustrativos para a apresentação aqui.

\section{A LEITURA DOS DEPOIMENTOS}

Pretendemos apresentar aqui uma leitura compreensiva dos depoimentos, buscando levantar pistas que possam sugerir o valor do modelo proposto para a compreensão da experiência religiosa no contexto do desenvolvimento pessoal.

Isso, no entanto, deverá ser feito de tal forma que cada sujeito, caso venha a ter contato com a análise feita, possa confirmá-la sem grandes dificuldades. Em outras palavras, a análise deve poder fazer sentido para seu próprio autor.

Acreditamos que isso não é verificar o modelo simplesmente em termos de ele ser verdadeiro ou não, mas sim avaliar sua capacidade compreensiva. Ele será um modelo útil se permitir compreender mais profundamente a pessoa em seu desenvolvimento religioso.

Acresce a isso que tal leitura poderá trazer também sugestões no sentido de aperfeiçoar o próprio modelo, enriquecendo suas descrições.

\section{Os depoimentos escolhidos}

1) Gabi, fem/21 , abril-maio/1999

Depoimento colhido por escrito, após conversa em grupo, em abril de 1999, seguido de outro, em maio do mesmo ano, respondendo às 3 perguntas específicas da instrução.

\section{1ำ relato}

Minha vida religiosa.

"Sou de uma família cristã, onde ia com meus pais na missa todos domingos, até meus 10 anos; depois fiz minha primeira comunhão, onde me confessei pela primeira e última vez, pois não me "senti bem", não sabia o que falar para o padre.

Minha mãe vai em benzedeiras para tirar "mau-olhado", acredita também que trabalhos feitos em centro de umbanda pode influenciar a vida das pessoas; apesar de eu não acreditar em nada disso respeito a opinião dela e de vez em quando exponho a minha opinião sobre tudo isso.

Quando tinha 16 anos minha avó faleceu, sofri muito com esta perda e fui buscar um "consolo" na doutrina espírita, lia muito sobre a reencarnação e isso me deu um alívio quando necessitei de ajuda.

Atualmente não freqüento missas, mas me sinto bem em ir até a igreja e rezar um pouco; converso com Deus todos os dias, pois acredito nele e em seu poder, apesar de não ter uma religião definida".

\section{2을 relato}

"Lembro de ter ficado mais perto do mistério da vida (de Deus)em alguns momentos em que sinto a nítida sensação de [que] já vivi determinados acontecimentos em minha ida, e nestes momentos sinto que há algum mistério e que existe uma força maior.

Embora tiveram momentos em minha vida em que duvidei desta força maior, de Deus, um destes momentos foi quando minha avó morreu, pensei como Deus poderia me separar dele [dela?]. Como estava sofrendo tanto duvidei dele. 
Toda noite ao me deitar eu rezo, na minha oração, eu rezo o Pai-Nosso, AveMaria, agradeço pelo dia, rezo para minha família e se algo muito importante irá acontecer no dia seguinte peço para Deus me iluminar. "

\section{Leitura do depoimento de Gabi}

Gabi, 21, é de família católica, tendo sido iniciada nos ritos infantis. Contudo mantém com a religião católica uma relação um tanto ambígua: sou de família cristã ... confessei pela primeira e última vez ...fui buscar consolo na doutrina espírita ...não freqüento missas ...me sinto bem em ir até a igreja e rezar um pouco... converso com Deus todos os dias... apesar de não ter uma religião definida.

Sua mãe também parece ter uma relação ambígua com a religião católica, pois: vai em benzedeiras ... acredita em trabalhos de umbanda.

A religião interior pessoal de Gabi está mais voltada para Deus, sem a mediação claramente reconhecida de uma instituição. Acredita no poder de Deus e expressa isso em orações. Converso com Deus todos os dias pois acredito em seu poder... toda noite ao me deitar eu rezo Pai Nosso, Ave Maria, agradeço pelo dia, peço pra Deus me iluminar.

Sua experiência de oração, contudo, é um tanto ritualística, baseada principalmente na crença do poder de Deus, com quem se relaciona como numa troca. Mas em experiências de "já vivido" sente que há um mistério na vida, que existe uma força maior.

O tipo de relação com o objeto religioso parece ser o da etapa 3, da menina, em nosso modelo: os objetos religiosos significados são externos e dotados de poder, mas existe a possibilidade de uma influência sobre eles através de ritos, preces, agradecimentos.

O objeto religioso é denominado como Deus (mistério, força maior, poder). Mas também Maria, a mãe de Jesus, pertence a esse universo (reza Ave Marias).
Não há menção a um momento intenso de experiência religiosa pessoal. Ela se movimenta mais no âmbito da religião recebida. No entanto, na experiência do "já vivido", algo evoca para ela o mistério religioso, o que aponta para necessidades de uma etapa posterior, mais coerente com sua etapa de vida, mas não suficientemente elaborada.

Em sua história há também uma ilustração interessante da etapa do adolescente, na medida em que se opõe aos pais, mas também passando para a etapa do jovem adulto, quando busca um pensamento pessoal. Referindo-se às crenças de sua mãe, diz: apesar de eu não acreditar em nada disso (benzedeiras e umbanda) respeito a opinião dela e de vez em quando exponho a minha opinião sobre tudo isso.

Isso parece ser o resumo de posição atual de Gabi: ela sente que não tem uma religião definida. Embora haja aspectos de outras etapas em sua vivência, este resumo a coloca bem na adolescência, como numa espécie de transição, mas que poderá também se fixar aí, caso nada de novo venha a ocorrer.

2) Euler, masc/25, maio de 1999.

Depoimento colhido por escrito, após conversa num grupo de 4 pessoas sobre 0 assunto. Houve para Euler 3 ondas de conversa seguidas de relatos escritos por ele em particular. Nas primeiras se falou sobre a história religiosa de cada um, e na última foram abordados assuntos mais específicos sobre momentos de experiência religiosa, dúvidas, e oração.

\section{$1^{\text {a }}$ relato}

"Até onde minha memória consegue explorar, minha experiência religiosa começou na religião católica; desde pequeno meus pais me levavam à missa. Devido ao fato de minha mãe na época dar aulas de catecismo logo me 
inseri num desses grupos. Freqüentei por volta de três anos antes de minha primeira comunhão.

Nessa época eu tinha bem fixado em mim certos dogmas como a existência de um céu, de um pai bondoso, do pecado, do poder da oração etc. Eu acreditava nesses preceitos até que um dia eu passei a questionar tudo isso. É claro que foi um processo onde primeiro não conseguia mais crer nas palavras do padre, transformando o ir à missa numa tortura; depois comecei a conciliar duas coisas inconciliáveis a meu ver, que são a fé e a razão. Fruto disso foi minha opção pela segunda. Eu já não conseguia acreditar em Adão e Eva, sabendo que o homem descende do macaco; o viver uma vida sem pecados ou arrependendo-se soava como "continue obedecendo o papai e a mamãe", ou "aja politicamente correto".

Nesse contexto abandonar a religião católica foi de um lado fruto de uma revolta muito própria do período de adolescência em que eu estava entrando, e também uma conseqüência de meu crescente interesse por arqueologia, história, futuramente parapsicologia e ufologia.

Na verdade eu estava à procura de uma verdade em que acreditar, já que a verdade imposta pelas religiões tradicionais eu decididamente não viria a procurar. A leitura de relatos de experiências fora do corpo, bem como de sucessos terapêuticos com a T.V.P. [Terapia de Vidas Passadas] me levaram a indagar por que eu mesmo não teria condições de chegar a ter uma experiência religiosa; que me mostrasse não pelo artifício da fé, mas pela experiência prática, que não terminamos aqui, que existe outra vida. De fato se considerarmos o desdobramento e a reencarnação como dogmas (existem e acabou) é bem fácil pensar em chegar a uma experiência individual que revele esses segredos da vida tão buscada em outras religiões. Fazendo uma outra análise pode-se dizer que nesse momento eu estava tentando botar em prática uma fé baseada numa espécie de razão. Um próximo passo nessa busca foi entrar na meditação.

Aliás se até hoje eu nunca tive oportunidades de experienciar nem experiências fora do corpo nem evidência da reencarnação, foi na meditação que eu aprendi que tão misterioso quanto o céu é nosso universo interior; nossa consciência ou nosso estado de consciência pode sofrer alterações motivadas pela respiração, o relaxamento de uma atitude mental favorável; se isso é inconsciente ou se entramos em contato com uma força superior não é algo que estou em condições de responder, mas que essas práticas produzem um efeito quase inacreditável em praticantes antigos, isso eu considero inegável. Falo isso não por experiência própria, mas por ter estado com tais praticantes nesse período. Essas pessoas chegam mesmo a ter uma experiência religiosa particular, seus relatos lembram delírios, porém nota-se que seja o que for é algo benéfico para elas.

Meu próximo passo foi relativizar e questionar tudo isso, que foi ao mesmo tempo em que ingressei na psicologia. Obras como O Futuro de uma llusão, do Freud, quando li senti como se alguém tivesse colocado em palavras o que eu sentia intuitivamente, era exatamente como eu via mas não enxergava.

Jung, no extremo oposto, escreve aspectos positivos da religião; são duas formas de pensar que se entrelaçam no modo como sou religioso hoje.

Sintetizando, minha experiência religiosa está intimamente ligada à razão; de certa forma ainda é preciso eu "ver para crer", não consigo "crer por crer", e esse é um caminho que eu sei que pode modificar. Meu crer em Deus está ligado à noção de infinito, de causa última, sopro da vida, noções que eu sei que são religiosas mas chego a elas pela razão; é 
assim que me constitui [constituo] como religioso.

\section{2 이ato}

"Levantando como pontos principais da minha experiência religiosa num primeiro momento meus questionamentos sobre alguns dogmas da religião católica e em seguida o meu contato com a literatura psicanalítica, especificamente "O Futuro de uma llusão", e Jung, vou tentando na medida do possível aprofundar minha reflexão nesses momentos. Comecei a questionar a religião católica quando eu estava com aproximadamente 10 anos. Até essa época eu freqüentava a missa, via a Igreja como a casa de Deus, bem cedo já comecei a fazer catecismo. Acho que por um lado foi a leitura que me levou a conhecer outros horizontes que, se não contraditórios, pelo menos diferentes da religião; passei a me interessar por outras coisas igualmente inexplicáveis, como Ufos, Triângulo das Bermudas etc.; por outro lado foi um momento em que encontrei não só coisas novas por livros mas também nos relacionamentos; mudei de colégio, abandonei mais a saia da mãe; enfim eu passei a me preocupar mais com molecagens, escola, os ufos do que com a religião.

Quanto à leitura de "O Futuro de uma Ilusão", acho que foi interessante, o que eu intuía ele escrevia, organizava, explicava, é um modo frio de encarar a experiência religiosa, me identificava quando li. Talvez devido ao tempo quase que integral que dedico a atividades racionais como estudante, continuo não pensando na religião a partir de mim, gosto do assunto, mas percebo que encaro como algo fora; isso acho que explica porque me identifiquei com essa concepção.

Porém também percebo que isso vai mudando, modos diferentes de encarar a religião vão chegando e se somando ao antigo.
Na verdade tenho dúvidas se estou falando da religião pois o que interessa minha concepção racional de religião se não a sinto? Tento entender mas não sinto? Ou será que entender ou buscar isso também é religião?

\section{3ำ relato}

"Houve um momento em que senti uma outra dimensão superior. Foiquando eu viajava nas redondezas de F., cidade paulista quase pertencente ao Paraná. Nesse trajeto que se realizava num local cheio de curvas, veio de encontro um outro carro em sentido contrário, com alta velocidade e em via de colidir. A colisão inevitavelmente iria lançar o carro onde eu estava num precipício. No momento em que ia ocorrer o carro desviou-se e com isso descontrolou-se mais ainda, vindo a cair. Paramoso carro ilesos, e observamoso [outro] carro despedaçado lá em baixo. Ninguém saiu do carro.

Nesse momento é como se o tempo parasse, pensamentos como "não chegou minha hora", "foi Deus", além de muitos outros indescritíveis com palavras se passaram em mim.

Porém assim como houve esses momentos de contato com um mistério, também existiu momentos de questionamentos, quanto à religião como um todo. Porém foram dúvidas sobre a religião institucionalizada, com normas e regras ditadas por um outro que, quer seja o padre, o pastor, o líder espiritual ou Jesus, apóstolos etc., eram vindas de fora. Passei a questionar o que levaria a pessoa a precisar disso; cheguei também a me dizer ateu, mas não no sentido de duvidar de tudo o que me ultrapassa, mas de não acreditar no Deus imposto pelas religiões.

Houve outros momentos em que tive a experiência desse mistério, digo experiência para distinguir do evento do quase acidente onde eu intui esse mistério. 
Na época desse evento eume interessava muito por experiências de viagem astral. Lia bastante e tentava utilizar algumas técnicas para produzir isso.

Uma noite após eu relaxar e nesse relaxamento antes do sono eu tentar produzir, não sei avaliar se por pura auto sugestão ou algo mais, o desdobramento, aconteceu de eu cairno sono e pouco depois começar a sonhar. Acontece que no meio do sonho eu me conscientizei que eu estava sonhando sem contudo acordar. Fiquei muito pouco dentro do sonho conscientizado e senti como se tivesse acordado mas eu não sentia meu corpo, nem a pressão da cama ou cobertor sobre ele. Era como se eu não tivesse peso e pairasse no ar. Nesse momento senti intenso medo, sabia o que estava acontecendo (naquela época eu acreditava sem questionar) e tenteime acalmar. Foi quando senti como se eu estivesse caindo, semelhante a uma pena que cai suavemente.

Senti uma espécie de choque quando supostamente penetrei em meu corpo, só que era como se não estivesse bem encaixado. Tentei gritar socorro, pular da cama, mas minha voz não saia, minha boca não mexia, $e$ meus músculos estavam também imóveis; já podia sentir meu corpo mas só isso, o que me deu mais desespero. De repente eu dei um pulo da cama, senti como se tivesse dado um grito e pensei que devia ter acordado todo mundo em casa, o que não ocorreu, acho que tive a impressão que gritei. Nunca mais tive outra experiência similar. Tive também experiência de sonhar que eu quebrei o braço, que um professor específico iria faltar, ou com eventos que futuramente ou no dia seguinte aconteceram, claro que não idêntico ao conteúdo do sonho, mas a similaridade era muito grande. Por isso eu, embora não tenha nenhuma religião, não pratique nem roga nem meditação, e nem tenha o hábito de rezar, eu não duvido que há mais mistérios entre o céu e a terra do que supõe nossa filosofia.

\section{LEITURA DO DEPOIMENTO DE EULER}

Euler, 25, não está simplesmente experimentando que a definição religiosa recebida dos pais já não lhe serve pois não vem de dentro de si mesmo. Isso seria a fase adolescente. Ele está ativamente buscando algo que o convença pessoalmente, a partir de sua experiência e de sua razão. Isso o coloca na etapa do jovem adulto.

Seu depoimento é quase didático. Sua religião infantil gira em torno de um gesto que tem significado sintético para ele: minha experiência religiosa começou na religião católica;desde pequeno meus pais me levavam à missa.

Depois ele menciona conceitos simples, quase simplórios, de dogmas como a existência do céu, de um pai bondoso, do pecado, do poder da oração, referindo-se assim ao que um menino podia entender, de forma bastante direta e literal.

Veio, então, o questionamento de tudo que vem de fora: não conseguia mais crer nas palavras do padre, transformando o ir à missa numa tortura. Era a adolescência. O abandono da religião foi apoiado também por seus estudos que avançavam nessa época. Mas a religião que ele abandonou foi a daqueles conceitos simplórios do menino.

Após isso sobreveio o período de busca de uma verdade que pudesse ser também apoiada pessoalmente em experiência e razão. É a etapa do jovem adulto em que ele se encontra: eu estava à procura de uma verdade em que acreditar. Esse período, ainda atual, parece que está sendo longo, cheio de buscas ativas, diversas experiências pessoais e questionamentos, não necessariamente em torno de religião, mas em torno do sentido de vida.

Embora questione a religião recebida, sente-se aberto para o que o possa ultrapassar; $E$ conclui seu relato com o que seria sua 
posição religiosa atual: embora não tenha nenhuma religião (...) eu não duvido que há mais mistérios entre o céu e a terra do que supõe nossa filosofia.

Euler vivencia claramente a etapa do jovem adulto, trabalhando dentro de si a busca de uma verdade que o possa convencer. É a busca de uma intimidade com o mundo, aberta a todas as questões, procurando receber daí uma compreensão da vida.

3) Zezo, masc/45, setembro de 1999.

Depoimento colhido por escrito, de uma só vez, após receber a instrução de uma auxiliar de pesquisa.

\section{Relato}

"Minhas experiências religiosas têm início quando ainda pequeno fiz o preparatório para a primeira comunhão e [o] que recordo muito fortemente daquela época, são o livro e a fita que recebi para estudos e posterior uso aos domingos, nas missas, para que fosse distinguido visualmente daqueles que ainda não tinham feito a primeira comunhão. Isso desde sempre foi para mim uma forma de individualizar-me dos demais e para os padres uma maneira que a igreja tinha ou tem para controle.

Um outro momento que tenho também muito forte na lembrança, é quando já jovem adulto, altamente contestador e muito sensível à aplicação dos ensinamentos religiosos recebidos nas missas dominicais, quando em um Domingo de ramos no sermão o padre falou sobre penitências e atos de pobrezas, $e$ outras balelas mais, manda que se recolha $o$ dízimo, e a cena em minha cabeça é a de um par de mãos sustentando uma bandeja cheia de dinheiro. Na Segunda feira, dia seguinte àquela cena, eu passo em frente a casa do padre para o trabalho, à pé, e tal não é minha surpresa, quando olho na garagem da casa, um automóvel Wolks zero km. na cor e ano que eu tanto sonhava, e aquilo foi a gota d'água para minha virada de mesa. Freqüentava uma religião que de uma certa forma vinha me dando informações distorcidas às pregadas por Jesus. Daí em diante revoltei-me e não freqüentei mais a igreja. Ficar sem vínculo espiritual jamais.

Andei à procura de alguns ensinamentos religiosos, mas não encontrava em nenhum deles o que procurava até deparar-me com uma Revista Acendedor (hoje Fonte de Luz), publicada pela Seicho-No-le na qual em um de seus artigos o Mestre Masaharu Tanigushi contava sua experiência também como uma pessoa que procurava um bom ensinamento religioso e que também como eu quando jovem era mais um desses rebeldes sem causa, mas que no fundo isso é o que serviria no futuro como estimulante para encontrar-se. Naquele momento identifiquei-me com aquele artigo e prometi para mim mesmo que iria conhecer aquela, que eu achava ser uma religião, e qual não foi meu espanto, quando em uma reunião que fui, tinha no palco um japonês de idade já avançada e em japonês, falava ao público comajuda de uma entérprete, mas o que eu vi e senti naquele momento, era que tudo que aquele senhor falava emjaponês, eu já sabia o que era, sem nunca ter falado ou aprendido aquela língua.

Oque estava sendo estudado, era alguma coisa que para mim sempre foi muito confusa, pois até então eu tinha aprendido que Jesus era Filho de Deus e eu era Filho do Pecado. Que para estar com o Pai ninguém iria até ele senão por intermédio de Jesus. E ali eu ouvi pela primeira vez que eu era Filho de Deus e que Deus está em mim. Ouvi também, que tudo que verdadeiramente existe são somente Deus e o que vem de Deus, portanto naquele momento tudo ficou muito claro pois até então a existência de Deus era uma coisa muito confusa que os padres incutem na cabeça da humanidade, e aíhoje eu posso comprovar o quão difícil foi para a humanidade ao longo da 
existência, ser treinada, condicionada a acreditar no que ouve e não ser contestador, não analisar até que ponto o que está sendo informado serve ou não, ou seja filtrar a informação de maneira que somente seja absorvido o que realmente acrescente.

Comecei a freqüentar esta filosofia de vida chamada Seicho-No-le em outubro de 1985, portanto na época tinha 30 anos e hoje 15 anos depois constato que grande parte do que sou hoje, muito alcanceipor ter encontrado neste ensinamento um orientador para o que viria a ser minha vida. Entendo que ensinamentos, seja lá de que natureza for, precisa pela concepção da palavra, ser entendido como tal, ou seja, ensinamento, e não como um amontoado de informações privilegiadas de uma minoria em detrimento da maioria. Hoje 15anos depois tenho para mim que oMovimento de lluminação da Humanidade na qual faço parte, tem como norma fundamental, a prática do sentimento de gratidão $e$ a manifestação de Amor em todos os atos.

É fácil? Eu acredito, e tenho todos os dias constatado, tal facilidade pois faço da vida humana uma vida divina e avanço crendo sempre na vitória infalível.

\section{LEITURA DO DEPOIMENTO DE ZEZO}

Zezo, 45, é de origem católica. A recordação marcante do livro e da fita da época de sua primeira comunhão, mostra como na infância pode haver objetos ou símbolos sintéticos do religioso ( $2^{\mathrm{a}}$ etapa de nosso modelo).

Hoje, no entanto, ele se identifica como praticante da filosofia Seicho-No-lê. Apesar de tudo, define-se em parte por oposição à sua religião de família. Seu depoimento é permeado de críticas veladas à igreja e aos padres: no sermão o padre falou sobre penitências e atos de pobrezas e outras balelas mais (...); freqüentava uma religião que (...) vinha me dando informações distorcidas às pregadas por Jesus (...); a existência de Deus era uma coisa muito confusa que os padres incutem na cabeça da humanidade (...). Considera a doutrina católica como informações privilegiadas de uma minoria em detrimento da maioria. Essa definição como por oposição se prende aos questionamentos adolescentes da identidade recebida (4 $4^{\underline{a}}$ etapa).

A ruptura com a religião de sua infância, porém, não o afastou de uma busca espiritual mais pessoal. Ele diz: ficar sem vínculo espiritual, jamais. Nesse movimento de busca (do jovem adulto, $5^{\mathrm{a}}$ etapa) ocorreu um encontro bastante profundo e marcante com um líder espiritual da Seicho-No-lê.

A forma como vive hoje essa "filosofia de vida" já aponta para uma certa fecundidade de sua atitude no meio. A prática do sentido de gratidão e a manifestação de amor em todos os atos, representam essa expansão de sua "religião" no meio. Faço da vida humana uma vida divina: esta afirmação aponta também para uma integração, em andamento, entre religião e vida, característica da etapa do adulto que parecesera sua ( $6^{\underline{a}}$ etapa).

A relação com o objeto religioso é pautada pelo movimento do qual faz parte, sua identidade pessoal sendo ainda bastante determinada pela instituição que segue. Uma retomada da pessoalidade dessa relação, será - desafio da próxima etapa a partir do questionamento de sua rotina( $7^{\mathrm{a}}$ etapa). Mas isso parece que ainda não aconteceu.

4) Blenson, masc/41, 1999.

Depois de uma conversa sobre o tema num grupo de 5 pessoas, em outra reunião cada um contou sua história religiosa pessoal. Em casa cada um escreveu essa história. Ela foi lida em uma terceira reunião onde 
compareceram apenas duas pessoas, sendo uma delas o Blenson. Houve nesta reunião uma conversa compreensiva a partir de cada leitura, e o pesquisador anotou algumas coisas dessa conversa.

\section{Reláto}

A minha história religiosa passa pela minha recordação, de quando ainda pequeno, da grande e evidente religiosidade de meus avós, Sr. Antônig de Oliveira, e dona Teófila dos Santos, os quais tinham grande devoção à Nossa Senhora Aparecida. Assim, minha mãe, foi batizada como nome de APARECIDA DE OLIVEIRA.

Ainda, quando pequeno, recordo-me das vezes em que brincava próximo da Igreja São Judas Tadeu, no bairro Lincoln, em X [cidade de Minas Gerais], minha cidade natal. Ocorre que eu brincava, porém com medo, pois os comentários eram que Judas havia sido o traidor de Jesus. Assim, como não tinha o conhecimento que hoje tenho, tinha um medo grande do Judas, sendo que muitas vezes passava correndo rápido em frente à lgreja.

Após meu conhecimento da qualificação de São Judas Tadeu como um dos apóstolos escolhido pelo próprio JESUS CRISTO, uma grande alegria me contemplou, a qual foi causadora do início de minha devoção a São Judas Tadeu.

Para minha alegria, apequena igreja que existia em X, hoje tornou-se Santuário de SÃO JUDAS TADEU, onde abriga um total de 1.600 pessoas nas concorridas missas e celebrações.

Tenho, dentro do possível, visitado várias igrejas deste importante apóstolo em São Paulo, Franca, Ibitinga, Itapira dentre outras.

Acredito que a religiosidade popular é um indicativo muito forte para uma verdadeira caminhada das pessoas junto com JESUS CRISTO.

\section{ANOTAÇÕESDO PESQUISADOR DURANTE A CONVERSA QUE SE SEGUIU}

Blenson fala de imagens que marcam, que são como um sinal da presença de Deus. Fala, por exemplo, de imagens do Sagrado Coração de Jesus em lugar de destaque nas paredes das casas, imagens de São Judas, de flores que são aí colocadas, etc. Menciona também outras manifestações exteriores que ele gosta de ver, como por exemplo, os bispos reunidos, a tradição apostólica, crucifixos. Comenta de como isso é diferente de ver nas casas pirâmides e duendes. Ele fica feliz, e sente-se motivado quando vê Santuários com muitas atividades humanitárias e bençãos. Fala da sua. alegria .quando vê os sinais de Deus se manifestando, os símbolos. É com essa fé que trabalha na comunidade. Quando tem uma devoção, procura difundí-la.

"Quando cheguei e ví aquela obra construída, a'quela organização, aquelas cadeiras, a melhor cadeira...; saí de lá encantado!". Disse isso contando a visita que fez à obra que estava sendo construída em um santuário.

Fala de sua devoção aos Santos. Diz que todo esse empenho com os santos que estão ao lado de Cristo, são parâmetros para a gente se animar. É para que Cristo seja glorificado.

Considera que a religiosidade popular não pode se perder.

Sentiu-se chamado ao serviço comunitário quando da leitura de um texto do Evangelho sobre a missão dos 72 discípulos, e por um contato significativo com um padre. Esse chamado se refere a serviço de comunidade, pastoral, amor e temor pela autoridade de Cristo.

\section{LEITURA DO DEPOIMENTO DE BLENSON}

O depoimento de Blenson, 41, muito reduzido e fragmentado, foi escolhido aqui, no 
entanto, porque ilustra uma religião que se apoia em manifestações exteriores simbólicas. Elas permeiam todo seu relato. O nome de sua mãe evoca toda a religião de seus avós. Outros nomes são destacados no relato (letras maiúsculas). Ele se refere, na conversa posterior, a imagens do Sagrado Coração de Jesus em lugar de destaque nas paredes das casas, imagens de São Judas, flores que são aí colocadas, crucifixos. Diz: Quando vi (...) aquela obra construída, aquela organização, aquelas cadeiras, a melhor cadeira..., saí de lá encantado! Esses são aspectos da religião da criança, cujos significados são concretizados em objetos simbólicos, sintéticos. Para Blenson, é claro, essas imagens estão complexificadas pelo seu desenvolvimento posterior. Mas permanece um estilo religioso, digamos assim, que remonta à religião da criança (2a etapa, dos 2 aos 6 anos aproximadamente), época de temores e amores. Ele se lembra, com efeito, do medo do Judas traidor, que o fazia passar correndo diante da igreja, e da posterior devoção ao Judas fiel. Temor e amor. E seu envolvimento atual com a igreja não é descrito, por exemplo, como em função de um clareamento de sua fé, mas sim como um chamado ao serviço comunitário que ele identifica com: amor $e$ temor pela autoridade de Cristo, conforme foi anotado pelo pesquisador na conversa posterior.

5) Zélia, fem/48, 1999.

Depoimento colhido por escrito em 3 ondas sucessivas, por um auxiliar de pesquisa, seguindo instruções gerais.

\section{9 relato}

Sou uma pessoa de 48 anos de idade, com formação católica. Meu pai praticamente nos obrigava a ir à missa todos os domingos, minha irmã e eu. Lembro-me com alegria, porém, de minha primeira comunhão, feita no colégio de freiras que freqüentava. Para mim sempre foi fácil ter uma fé, acreditar em Deus. Várias vezes entrava em igrejas, muitas vezes vazias, e ali ficava um pouco, rezando. Gosto da idéia de termos um Pai que nos ama, apesar dos nossos defeitos. Também fico especialmente feliz em acreditar que existe uma força superior que sabe para onde estamos indo, que tem nossos destinos em Suas mãos, pois o mais fácil é nos sentirmos perdidos no meio do caminho...

Penso também que o Ser humano ainda não consegue compreender totalmente $o$ significado de Deus em suas vidas. Mas pessoalmente, confiar em Deus é o mesmo que acreditar que todas as coisas difíceis têm jeito e que estamos seguros, confiantes. É assim que eu vejo Deus em minha vida: a maior força do Universo.

Fico entristecida quando estou num ambiente e debocham de Deus, mas não julgo ninguém pois cada um pode pensar como quiser.

\section{2ำ relato}

Justamente agora encontro-menuma fase de total desprendimento de religiões - Penso que a religião é um fagelo [flagelo?] e o ser humano enlouquece com a possibilidade de Deus - Não compreende, nem se conhece para admitirum Deus. Pensamos que estamos a salvo se acreditarmos que Deus existe e tudo o que vemos são decepções e frustrações. Então almejamos o total desprendimento e a liberdade - Ser livre de dogmas, de fanatismos. Almejo isso - Livra-me de qualquer sentido de crença. Para não me decepcionar. Mas depois bate a culpa - Será que estou certa, será que vou ficar bem?

São perguntas que também não tem respostas...

Não é negar Deus - Mas chegar a um ponto que tem que se admitir que não se pode alcançar Deus. Mas talvez seja só um estado 
de espírito, em que passo por muitas pressões (?) e pouca compreensão. Nada pessoal, só um estado de espírito.

\section{3ำ relato}

Embora meu momento atual seja de um pouco de ceticismo, devo reconhecer que sempre tive facilidade de acreditar em Deus. O Pai, o Amigo. a Perfeito. A Luz do Mundo. O Príncipe da Paz. E esse sentimento é tão forte e sempre foi o meu refúgio nos momentos ruins. Sempre tive a certeza que existe um Ser Supremo que está acima de nós e que nos ama e nos protege. Mas se pensamos com a razão, onde está? No céu? E por que não se apresenta? Por que é só Espírito. Mas por que não o vemos? São essas perguntas que nos "enlouquecem" um pouco mas acho que é aí que devemos colocar nossa fé em ação e acreditar somente. Crer, simplesmente - É isso que tenho feito em toda minha vida. Ler a Bíblia é um desafio que tenho me proposto. Existem trechos que são belíssimos e o mais tocante refere-se ao perdão. Pedro aproximase de Jesus e pergunta: Mestre, quantas vezes devo perdoar meu irmão? Sete vezes? E Jesus responde: "Setenta vezes sete". Ou seja: infinitamente.

Para nós, seres humanos é tão difícil perdoar. a mais fácil é odiar e tramar vinganças... Mas se dermos ouvidos à palavra de Jesus, perdoamos com facilidade, tiramos de nossos corações a mágoa, a decepção. Temos que viver essa fé.

\section{LEITURA DO DEPOIMENTO DE ZÉLIA}

Esse depoimento foi escolhido para ilustrar a possível presença forte de remanescências da $1^{\underline{a}}$ etapa.

A religião de Zélia, 48, é permeada pela dúvida ou hesitação: gosto da idéia de termos um Pai que nos ama... penso também que o ser humano ainda não consegue compreender totalmente o significado de Deus em suas vidas ...o ser humano enlouquece com a possibilidade de Deus... meu momento atual [é] de um pouco de ceticismo... sempre tive facilidade de acreditar em Deus.

Ela não se diz católica, mas com formação católica, não se comprometendo assim com uma posição pessoal clara. A primeira coisa de que se lembra é: meu pai praticamente nos obrigava a ir à missa todos os domingos. Essa dificuldade de tomar posição, aliada à lembrança de um constrangimento por parte do pai, faz pensar em algo relacionado com confiança básica. No que diz respeito à religião, ao sentido último, ela se sente um pouco com o pé atrás, sem saber se pode confiar.

Zélia vê a Deus como um Pai que nos ama ... a maior força do Universo. Reconhece que tem facilidade de acreditarem Deus apesar de todas as dúvidas. Ou seja, sua religião se mostra quase como um desejo, e ela luta para que se torne real. Luta com os questionamentos.

Talvez a saída concreta que antevê para esse dilema seja tomando posição construtiva nas relações humanas ameaçadas pelo ódio: para nós seres humanos é tão difícil perdoar. a mais fácil é odiar e tramar vinganças... Mas se dermos ouvidos às palavras de Jesus, perdoamos com facilidade, tiramos de nossos corações a mágoa, a decepção. Temos que viver essa fé. É assim que ela termina seu depoimento.

Essa tomada de posição concreta, para além de todas as dúvidas e raciocínios teóricos, faz pensar na etapa do adulto maduro ( $7^{\underline{a}}$ etapa) onde também haveria uma espécie de superação do pensamento linear. Isso corresponde de fato à sua idade cronológica.

6) Daniela, fem/48, 1999.

Houve duas conversas específicas sobre o tema, do pesquisador com Daniela. Após a 
primeira ela escreveu um depoimento. Depois foi pedido que aprofundasse alguns pontos. Ela escreveu então um outro que considerou mais completo, substituindo o primeiro.

\section{Relato}

As vivências mais importantes que eu tive durante minha infância, giraram em torno da figura de minha avó e de alguns santos de sua devoção. As lembranças que eu tenho deste período envolvem o uso de medalhinhas de Sta. Clara, o ouvir histórias sobre Sto Antônio e a cruz de São Camilo que eu usava presa por um alfinete junto às minhas roupas.

$\mathrm{Na}$ escola [um colégio de freiras], aconteceu a preparação para a primeira Comunhão e os momentos de ida à Capela. Da Capela, especialmente, tenho a recordação de um lugar muito bonito onde eu gostava de estar e onde de algum modo, agora não sei explicar exatamente como, eu sentia a presença de Deus.

Já um pouco mais velha, comecei a ir à Missa. Um momento que nem sempre eu conseguia compreender seu significado. As missas eram celebradas em latim, as homilias, "acho" não procuravam trazer as reflexões sobre o Evangelho para a nossa vida. Passada esta primeira fase, de uma religiosidade mais "infantil",me lembro de ter "abandonado" por um tempo uma vivência mais explícita, ou "externa" da experiência religiosa, mas não de Deus, com quem eu me comunicava por meio de oração. Cheguei a participar durante minha adolescência de alguns retiros do Colégio onde eu estudava, mas eram situações que aconteciam esporadicamente.

Já morando em $X$ [cidade grande do interior],depois de entrar na Faculdade, tive experiências diferentes, desencadeadas por amigos que conheci na república onde morava. Diferentes na medida em que pela primeira vez conheci pessoas, leigos e padres, que tinham uma prática religiosa e pessoal com as quais eu nunca tinha tido a oportunidade de ter contato. Experiências de celebrações em casa, que não tinham folheto, e uma experiência de Deus muito mais concreta, em situações de vida de cada um de nós.

O fato de ser uma coisa tão diferente, por outro lado, me levou a "achar" que as celebrações nas Igrejas não diziam nada, eram distantes da minha vida. Então com isso a minha "vivência" continuou acontecendo esporadicamente em contextos "alternativos". Eu só participava de celebrações com padres amigos. Esse foi um longo período, que passou por meu casamento, pelo nascimento dos meus três filhos.

Quando minha filha mais velha tinha por volta de 10 anos, e que eu comecei a procurar por um lugar para que ela se preparasse para receber a primeira Eucaristia, é que reconheço que passei a viver um outro momento na história das minhas experiências religiosas. Neste período, sim, tenho a lembrança bem forte de ter sentido de forma bastante intensa a necessidade de viver uma experiência de Deus.

Contudo, ainda nessa fase, o predomínio da "forma" e do lugar aonde viver esta experiência. A marca do "alternativo" ainda era forte e acabei encontrando a Comunidade $Y$, que se reunia na escola $Z$, e era acompanhada pelo padre Antônio. Um grupo pequeno de pessoas que se reunia semanalmente para a celebração da Eucaristia e tinha o privilégio de ter um pastor só para si. Durante mais de 10 anos freqüentei a comunidade regularmente, participando intensamente de todos os seus momentos, celebrações, retiros, reuniões informais para reflexão bíblica.

Penso que já nessa fase a experiência de Deus estava definitivamente integrada à minha vida, e a busca de aprofundamento na reflexão, e também pela realização de algo mais concreto, não parou mais.

De alguns anos pra cá, contudo, uma nova mudança. Penso que a marca dessa 
mudança foi o desejo de fazer as coisas menos "automaticamente". A tentativa de ir mais fundo significava também conhecer mais a respeito das questões que envolviam a religião católica. "Entender" melhor, por exemplo, o sentido da celebração Eucarística. O que cada momento da missa representava, compreender mais a simbologia também das celebrações como as que eu encontrava na leitura do Evangelho.

Também a busca por ações mais concretas significava a necessidade de selar de maneira mais definitiva o desejo de estar comprometida com Deus, sentindo que de algum modo eu precisava oferecer ou retribuir aquilo que eu recebia.

Penso que nesta fase senti de fato de forma mais intensa, uma outra dimensão da realidade, uma dimensão até misteriosa e diferente, mas que me movia de dentro para fora.

Me parece que a necessidade de viver a experiência de Deus ia se constituindo de dois modos, um que era um olhar mais profundo para dentro de mim mesma, olhar este orientado pela palavra do PAl, e um sair de mim, mais voltado para a minha ação no mundo. Juntando as duas coisas, viver concretamente a palavra de Deus. Considerando a dificuldade que isso de fato representa, então a necessidade de alimentar constantemente, incessantemente essa experiência. A necessidade de olhar diferente as coisas do dia a dia, e ao mesmo tempo viver isto na minha inteira [sic].

\section{LEITURA DO DEPOIMENTO DE DANIELA}

A história de Daniela, 48, se apresenta bem dividida em fases, de forma também quase didática para nossos propósitos.

Do tempo de criança sua lembrança se concentra em objetos-símbolo, e histórias: medalhinhas ... cruz de São Camilo... histórias de Santo Antônio... momentos de ida à capela; e o significado da capela onde sem saber explicar exatamente como, ela sentia a presença de Deus. Isso ilustra as etapas 2 e 3.

$\mathrm{Na}$ adolescência foi se desinteressando das práticas que não entendia, e, como diz, me lembro de ter abandonado por um tempo uma vivência mais explícita ou externa da experiência religiosa, mas não de Deus, com quem eu me comunicava por meio da oração.

Comojovem adulta pôde terexperiências diferentes, de uma prática religiosa... pessoal. Neste contexto fala de uma experiência de Deus muito mais concreta. Juntamente com isso houve um afastamento de práticas mais anônimas e impessoais.

A etapa seguinte inaugura-se já com a necessidade de preparar os filhos para participarem de forma mais consciente da vida sacramental da igreja. Aqui também torna-se mais aguda a necessidade de viver uma experiência de Deus, como se as anteriores experiências ainda não tivessem sido suficientemente pessoais, pois foram desencadeadas por amigos e, de certa forma, ainda muito ligadas ao grupo (característica bem adolescente). No contexto da expansão adulta, ela retoma aprofundamentos da etapa da intimidade. Aprofundamento na reflexão, e realização de algo mais concreto, são expressões que caracterizam essa etapa adulta para Daniela.

Sem grandes marcas de separação, começa a surgir outra etapa: o desejo de fazer as coisas menos automaticamente, a tentativa de ir mais fundo. $\mathrm{E}$ juntamente com isso a busca por ações mais concretas, marcando o desejo de estar comprometida com Deus. Ela sente isso como a necessidade de um olhar diferente para as coisas do dia a dia. É a busca de uma nova integração pessoal, na etapa do adulto amadurecido (1aㅡ etapa) que já vai se manifestando. 
7) Mariana, fem/74, maio de 1999.

Depoimento gravado a partir de uma instrução geral solicitando a história religiosa, e posteriormente transcrito sem as falas do entrevistador. Colhido por um auxiliar de pesquisa.

\section{Relato}

Eu aprendi toda minha religião católica com meu avô que veio da Itália, ele era um homem que sabia muito sobre a religião católica. Ele dava aulas de religião nas fazendas e até rezava missas. Nessa época eu sempre acompanhava ele e assim aprendi toda a religião católica.

Até hoje eu nunca mudei e nunca pensei em mudar de religião. Comecei com 6 ou 7 anos já a entender a religião; eu ia sempre na missa; comecei a cantar em coro da igreja, foi na época em que eu mudei do sítio para a cidade.

Deus para mim é tudo, eu já recebi muitas graças, eu creio muito em Deus.

Eu rezo muito, tenho minhas orações, faço grupo de terço, tem um outro grupo de reza para Nossa Senhora da Aparecida, que tem uma imagem de uma santa que vai passando de pessoa em pessoa do grupo.

Quando tem alguém doente eu sempre rezo muito e peço e recebo muitas graças.

Uma vez minha filha estava muito doente, com uma doença grave, fazia um mês que ela estava na cama e não conseguia andar, e eu sempre fazendo minhas novenas ao Sagrado Coração, até que um dia quando eu já estava preparando o prato para ela almoçar, eu ia levar na cama porque ela não conseguia andar, quando vi ela tinha levantado e estava indo na mesa para almoçar. Era um Domingo. Eu acredito que isso foi um milagre muito grande que eu recebi porque eu estava rezando muito para Nossa Senhora. A partir desse dia ela melhorou rápido e sarou. [ao contar esse episódio, chorou]

Eu também não rezo só pra conseguir graças, eu peço muito pra Deus proteger meus filhos e netos nas estradas, rezo quando eles ficam doentes, rezo por meus netos na escola, peço para ajudar nesses problemas tão sérios que estão acontecendo, assassinato, roubo. Então toda noite minhas orações são para os meus filhos e para os meus netos. Peço pra Deus guardar eles e eu tenho muita fé que nada acontece com eles.

Nunca deixe de acreditarem Deus nem por pensamento. Eu acho que a religião está acima de tudo porque uma pessoa sem religião não é nada, é uma pessoa que não pode contar com nada porque o que que ela vai contar se ela não tem religião.

Eu tive mais mostras da presença de Deus não só uma vez, várias vezes e sempre pordoença. Há pouco tempo tinha uma netinha doente e tanto a neta como a filha não queriam fazer uma cirurgia. E eu fui pedindo para que Deus iluminasse eles porque ela precisava fazer essa cirurgia para sarar. Foi quando o médico chamou e as duas não tiveram tempo de decidir ou não deixar de fazer. Minha neta já foi encaminhada para fazer a cirurgia, que deu tudo certo e hoje ela está melhor.

\section{LEITURA DO DEPOIMENTO DE MARIANA}

Mariana, 74, tem consciência que sua religião foi recebida por tradição, através da pessoa de seu avô que sabia muito sobre a religião católica. Ela apreendeu esse saber e nunca pensou em mudar de religião. Pelo contexto fica claro que não se tratou de um aprendizado meramente teórico, mas sim prático-vivencial. A frase que resume o significado desse aprendizado é: Deus para mim é tudo, eu já recebi muitas graças, eu creio muito em Deus. E também: eu acho que a religião está acima de tudo porque uma 
pessoa sem religião não é nada. Não se trata de definições conceituais, mas vivenciais, associadas a experiências de relação, de confiança, de proteção.

Sua oração não é presa ao esquema de obtenção de benefícios por influência do orante, embora transcorra ligada a uma experiência de proteção contínua. É como um movimentar-se confiante nesse ambiente religioso, divino, de proteção. Não rezo só para conseguir graças ... peço pra Deus guardar eles e eu tenho muita fé que nada acontece com eles.

O objeto religioso não é algo à parte da pessoa, embora esteja acima. É tudo. Está aqui implícita uma concepção de transcendência que envolve a pessoa, e não é um objeto como os outros, apenas mais poderoso. Esse objeto é constituído numa relação que, mesmo tendo por vezes a linguagem da prece, é muito maior e mais abrangente. Sugere um movimentar-se num mundo divino. Por isso a ligação entre religião e vida é real e muito grande. Isso situa Mariana nas etapas mais evoluídas do desenvolvimento religioso: do adulto, adulto maduro e mais velho. Seria necessário saber mais sobre sua história de vida para discernir qual das três. É interessante notar, no entanto, que a elaboração conceitual não é grande nem sofisticada. Pelo contrário, é bastante simples, embora carregada de muita força. Parece que para ela a precisão dos conceitos não é o que mais importa, o que denota também uma certa relativização da instituição. Esse é um dado que aponta para a etapa do adulto mais velho.

8) Norival, masc/81, maio de 1999.

Depoimento colhido por uma auxiliar de pesquisa, após uma única conversa instrução.

\section{Relato}

Pensando bem, quase posso afirmar que, na extensão da palavra, praticamente, não tenho religião. Criado e educado na religião católica, nunca pude me entrosar com ela ou com outra qualquer, sem, contudo, atinar com o motivo dessa apatia, que me acompanha desde a infância.

Tenho comigo um retrato da minha turma da $1^{a}$ comunhão, onde os demais contritos, de mãos postas, com a humildade que a ocasião requeria, foram retratados; eu, acintosamente, me mantive de braços cruzados, olhar desafiador, como se fosse o dono do mundo. Até hoje, quando revejo tal retrato, não consigo conceber reação tão arrogante e descabida, engendrada no cérebro de uma criança de apenas sete anos.

No entanto, no decorrer dos anos, que não são poucos, convivendo com pessoas de credos religiosos variados, jamais me passou pela mente pensamento de desrespeito e menosprezo às suas crenças filosóficas.

Graças a Deus, mantenho minha crença própria, que se resume a partir de dois mandamentos da Igreja Católica: "Amar a Deus, incondicionalmente, sobre tudo e todas as coisas, e ao próximo "quase" como a mim mesmo". - Vai aqui um ponto fraco, que também não sei explicar:não consigo conceber amar ao próximo como a mim mesmo, o que reservo aos grandes privilegiados.

Assim vou vivendo sem queixas nem remorsos, usando o beneplácito de Deus, que nunca me desamparou, proporcionando-me, sempre, tudo que ambicionei na vida: o essencial para viver modestamente, usufruindo, sofregamente, o Dom Divino que Deus dá aos homens ou seja: uma família bem constituída, filhos amorosos, amigos numerosos e leais, saúde e integridade.

Minha religião? - A vida! ...

\section{LEITURA DO DEPOIMENTO DE NORIVAL}

Norival tem um depoimento aparentemente contraditório. Praticamente não tenho 
religião ... graças a Deus mantenho minha crença própria que se resume a partir de dois mandamentos da Igreja Católica ... usufruindo o Dom Divino... minha religião? A vida.

No entanto essa contradição é aparente. Na verdade há uma relativização da instituição religiosa sem eliminar a postura de veneração indireta por Deus, o objeto religioso. A vida é dom de Deus; a religião é a vida. Isso aponta para a penúltima etapa de nosso modelo (o adulto mais velho: $8^{\underline{a}}$ etapa). A integração entre religião e vida é tal que esses dois âmbitos da experiência tendem a se fundir. $E$ é interessante que neste caso isso esteja acontecendo numa pessoa sem religião, no sentido de rótulo externo.

O aspecto de descobrir a vida simplesmente, para além dos apoios externos, neste caso se verifica na expressão: vou vivendo sem queixas nem remorsos. Quando ele se refere a família bem constituída, filhos amorosos, amigos numerosos e leais, saúde e integridade,como sendo tudo que ambicionou na vida, isso, na verdade, não parece ser "condição" de sua atitude sábia, pois ele se refere também a usufruir o Dom divino dentro de uma concepção de que Deus não desampara o ser humano. Seu apoio não parece estar naqueles fatos em si, mas sim no modo como os vê, ou como vê a vida.

Como entender a atitude arrogante e acintosa para com os ritos religiosos, de que se lembra quando criança? Ele mesmo não consegue decifrar o enigma. Há aqui uma necessidade grande de independência que, com certeza, lança raízes em afetos sentidos anteriormente a essa lembrança. O olhar desafiador tem algo de recusa ao que está posto, ou de não confiança solta (1 $1^{\underline{a}}$ etapa). Isso pode ter marcado seu estilo religioso, ou até seus conteúdos religiosos. Mas as sínteses sucessivas que ele foi fazendo através da vida (e que, com esses dados, podemos apenas supor), não foram impedidas.

\section{DISCUTINDO E CONCLUINDO}

A primeira coisa que podemos dizer é que foi possível utilizar nosso modelo de desenvolvimento religioso na leitura dos depoimentos. Não somente isso foi possível, mas também permitiu uma compreensão aprofundada dos diversos relatos, no contexto de um mesmo quadro de referência geral. O que possibilita, então, alguma comparação entre eles.

Em segundo lugar, podemos dizer que fica sugerida uma íntima relação entre o psicológico e o religioso. Isso decorre da própria natureza teórica do modelo construído e aqui usado.

Em terceiro lugar, também ficou claro que o grau de desenvolvimento religioso não depende da religião professada pela pessoa, e sim, mais do tipo de relação que ela tem com o objeto religioso, mesmo quando este não é explicitamente conceituado.

É claro que cada uma dessas conclusões tem implicações teóricas e para a pesquisa. Devemos explicitar algumas. Antes, porém, podemos elencar algumas outras conclusões.

A tentativa de encontrar a etapa em que se encontra uma determinada pessoa, mostrou, em acréscimo, que sua própria experiência poderia enriquecer o modelo em termos descritivos. Isso não apenas em termos gerais, mas em termos de se acrescentar descritores específicos para algumas etapas.

Em termos gerais isso quer, no fundo, dizer que este estudo tem um caráter exploratório, podendo ser continuamente enriquecido, ou mesmo modificado, por novos achados. Nesse sentido seria importante analisarmos mais e mais depoimentos, de sujeitos das mais diversas condições. Como já comentamos, nesta amostra, por coincidência, havia condições comuns a quase todos os sujeitos, limitando assim o alcance das conclusões. Por exemplo, eram todos provenientes de famílias de tradição católica, 
mesmo quando não mais se diziam dessa religião. Seria interessante buscar amostras de outras tradições ou de outras condições culturais.

Em termos específicos, já em nossa amostra foi possível sugerir alguns acréscimos à nossa descrição. Por exemplo, o fato de, na etapa da criança e do menino ou menina, os ensinamentos religiosos serem interpretados de forma literal, simplória em relação à sua compreensão por pessoas de etapa mais avançada. Esse caráter literal das interpretações religiosas nessas idades, aliás, já foi descrito por Fowler (1993), e poderia ser acrescentado em nossa descrição.

A leitura dos depoimentos mostrou ainda que há características de várias etapas num só depoimento, seja porque ele narra uma evolução, seja porque, mesmo no momento presente, características de outras etapas se fazem presentes e manifestas. Este último ponto sugere "estilos" diferentes de religião (vinculados a determinadas etapas), ou mesmo "bloqueios" em etapas anteriores e que se fazem manifestar na atualidade da pessoa, dificultando um desenvolvimento maior.

Além disso, nosso estudo mostrou que a etapa que se manifesta predominantemente para uma pessoa, nem sempre coincide com sua idade cronológica. Ou seja, há espaço para se pensar em subdesenvolvimento religioso, e em ajuda religiosa.

Podemos agora voltar para algumas implicações. Houve uma noção de religião que guiou a leitura que fizemos. Embora não totalmente explícita, ela existiu e de forma coerente, pois há uma unidade de olhar que se manifesta na leitura. Que noção é essa? Em primeiro lugar fica clara uma diferença entre uma religião externa, declarada, e outra interna, mais vivida. A noção que aqui nos guiou corresponde mais à interna, com certeza. Por mais que a religião exterior seja muitas vezes, embora nem sempre, contexto para a religião interior, parece certo que foi da interior que aqui se tratou. Se quisermos trabalhar a questão do desenvolvimento religioso do ponto de vista psicológico, é importante que isso fique claro.

Mas qual o conteúdo dessa religião? Em que consiste ela? A leitura dos depoimentos apontou para a direção de uma forma de relação com o objeto religioso. Só que, "objeto religioso", aqui, não é algo conceituado como tal necessariamente pelo sujeito. "Objeto religioso" é aquilo que de fato ocupa o lugar do último, do mais radical, do absolutamente abrangente, qualquer que seja o nome que a pessoa dê a isso, ou mesmo, que ela não the dê nome nenhum ou nem tenha consciência clara da importância disso em termos psicológicos. Uma imagem pode expressar o que isso quer dizer. É a imagem do móbile: uma escultura frágil, balançante, e que se sustenta em vários pontos de equilíbrio articulados, mas todos eles dependentes de um ponto central que está fora do próprio móbile: em geral o teto. O objeto religioso é aquilo que está na função do teto, psicologicamente falando. Ele está fora do móbile, embora esse fora esteja também no íntimo, pois é ele que sustenta todo o equilíbrio dinâmico.

O correspondente psicológico do objeto religioso é o que Erich Fromm (1974) chama de estrutura de orientação e devoção. Segundo ele, no ser humano existe uma necessidade de tal estrutura, ou seja, uma necessidade de sentido global. Essa necessidade foi suprida historicamente pelas religiões, e ainda hoje o é na maioria dos casos. Mas isso não é necessário.

Podemos dizer que a palavra religião tem dois sentidos. Um, relativoa Deus. Ser religioso é ter fé em um Deus. Outro, relativo a um sentido global. Ser religioso é estar ligado num sentido global de tudo, numa totalidade; é estar "re-ligado" a uma fonte, ou ter feito assim uma "re-leitura" do mundo, com- 
preendendo e vivendo seu significado mais radical. No primeiro sentido temos as grandes religiões monoteístas (judaísmo, cristianismo, islamismo). No segundo sentido temos o budismo primitivo ou algumas doutrinas orientais (que não têm necessariamente um Deus). O que parece importante aqui é compreender que esses dois sentidos não são paralelos, mas conceitualmente hierarquizados. A religião no sentido teísta, e principalmente monoteísta, se enraíza numa necessidade de sentido e de ligação com o todo, representando uma evolução histórica da experiência e das elaborações da humanidade.

É o que nos diz, por exemplo, o filósofo Cassirer (1972). Ele considera a evolução da religião a partir da magia e do mito, os quais pressupunham uma profunda percepção da unidade do mundo. Nesse contexto, a ligação com o todo exigia uma pureza objetiva, ritual, material. Houve uma profunda evolução de significados religiosos, a partir daí. A pureza que faz essa ligação "religiosa" com o todo, passou a ser a pureza de coração. A religião passou a ser expressão de um novo ideal positivo de liberdade humana (Cassirer, 1972/1944: 172), superando a rigidez dos sistemas de ligação. É no contexto dessa nova maneira de sentir, instrumentalizada pela ponta evolutiva das religiões, que nos situamos atualmente, acreditemos ou não num Deus.

Embora não seja muito usual, podemos falar, então, de religião, até mesmo para um ateu. Sua "religião" será sua posição interior diante do mistério do mundo, em termos de sentido. É assim que está sendo usado aqui o termo. Nesse sentido é válido afirmar que a religião é uma necessidade humana que pode ou não estar sendo bem atendida.

A partir daí, o que pode ser o "objeto religioso"? Nesta pesquisa esse termo designou, vemos agora mais claro, aquilo que é visado pela atitude "religiosa" (no sentido de re-ligação interior), qualquer que seja a crença da pessoa. Claro está que o objeto religioso está sendo elaborado seja na evolução individual (através das experiências concretas de vida que se constituem em etapas do desenvolvimento religioso), seja na evolução histórica (através das experiências da humanidade na sua lida com o sentido). E esses dois âmbitos de experiência são mutuamente dependentes.

Ao que parece esses são conceitoschave, que estão por trás dessa pesquisa. Se assim for, fica clara a importância psicológica e cultural da religião (definida de forma abrangente). Isso perpassa a leitura que fizemos dos depoimentos. Mas ao mesmo tempo mostra que a tarefa de clarear essas questões não fica terminada. A pesquisa deve continuar.

Ressaltaria ainda dois últimos pontos. Para se chegar ao vivido da relação com o objeto religioso (no sentido em que definimos aqui) se faz necessário uma entrevista em profundidade. Dificilmente um simples questionário chegaria lá. É necessário progressivamente mobilizar o sujeito para que ele chegue ao que se quer pesquisar. A estratégia que foi aqui utilizada fica, então, justificada.

Finalmente, parece necessário articular melhor a questão da importância da experiência religiosa,como contato ou como algo marcante para o sujeito, na descrição das etapas. A análise que foi aqui feita permite levantar a hipótese que esta experiência pode ser mais importante para o desenvolvimento do que o que foi aqui considerado. Quase nenhum sujeito falou de momentos decisivos, quase como uma conversão, em seu depoimento. Com certeza seria necessário comparar estes depoimentos com outros onde fossem relatadas experiências marcantes e mutativas. Isso poderia trazer, quem sabe, enriquecimento ao nosso modelo. 


\section{REFERÊNCIAS BIBLIOGRÁFICAS}

AMATUZZI, Mauro M. (1988). Retratos da Vida: caminhos de Crescimento e Ajuda. $2^{\underline{a}}$ ed. São Paulo, Ed. AM. (A $1^{\underline{a}}$ ed., com o título Crescimento e Ajuda: veredas em Psicologia, da Cortez editora, é de 1980).

AMATUZZI, M; ECHEVERRIA, D; BRISOLA, E; \& GIOVELLI, L. (1996). Psicologia na Comunidade: uma experiência. Campinas, SP, Ed. Alínea.

AMATUZZI, Mauro M. (1998). A experiência religiosa: busca de uma definição. Estudos de Psicologia, 15 (1), p.49-65.

AMATUZZI, Mauro M. (1998). A experiência religiosa: estudando depoimentos. Estudos de Psicologia, 15 (2), p.3-27.

AMATUZZI, Mauro M. (2000). O desenvolvimento religioso: uma hipótese psicológica. Estudos de Psicologia. (Publicado no no anterior a este.)

CAMINO, Cleonice P. dos S. (1998). Educação Moral: doutrinação ou debate? In: DE MOURA, Maria Lúcia S., CORREA, Jane; \& SPINILLO, Alina (orgs). Pesquisas Brasileiras em Psicologia do Desenvolvimento. Rio de Janeiro, Ed. UERJ, p.111-139.

CASSIRER, E. (1972/1944). Antropologia Filosófica - Ensaio sobre o Homem (Introdução a uma Filosofia da Cultura
Humana). Trad. de Dr. Vicente Felix de Queiroz. S. Paulo, Ed. Mestre Jou.

ERICKSON, Erik H. (1998). O ciclo de vida completo. Porto Alegre, SR, Artmed. (Original americano)

FOWLER, James (1992). Estágios da Fé: a psicologia do desenvolvimento humano e a busca de sentido. São Leopoldo, RS, Sinodal. (Original americano de 1981)

FROMM, Erich (1974/1944). Análise do Homem. 9a ed. Trad. de Octávio Alves Velho. Rio de Janeiro, Zahar.

JUNG, Gari G. (1979/1934). O Eu e o Inconsciente. Trad. de Dora Ferreira da Silva. Petrópolis, Vozes. (Obras Completas de C.G. Jung, V.7, T.2)

MASLOW, Abraham H. (s/d). Introdução à Psicologia do Ser. Rio de Janeiro, Eldorado. (O texto mais recente desta coletânea é de 1963)

OSER, Fritz K. \& REICH, Helmud (Instituto Pedagógico da Universidade de Friburgo, Suíça) (1996). Psychological perspectives on religious development. World Psychology 2(3-4): 365-396.

PIAGET, Jean (1967). Seis Estudos de Psicologia, Trad. Maria Alice Magalhães D'Amorim e Paulo Sérgio Lima Silva. Rio de Janeiro, Forense-Universitária. (Original em francês) 